\title{
THE POTENTIAL OF TWO TYPES OF URBAN FLOODING TO CAUSE MATERIAL DAMAGES IN LISBON, PORTUGAL
}

\author{
MIGUEL LEAL \& CATARINA RAMOS \\ Centro de Estudos Geográficos, Instituto de Geografia e Ordenamento do Território, \\ Universidade de Lisboa, Portugal
}

\begin{abstract}
The incapacity to cope with heavy rainfall events leads to flooding in urban areas. Urban flooding is usually divided into pluvial flooding, sewer flooding, among others. Determining which of these types was responsible to cause a flooding occurrence is, in most cases, an error-prone task, because it can be triggered by more than one of them and there is frequently an overlap in their extent.

Given these problems, a classification based on the hydro-geomorphological features was applied to Lisbon, in which the relief and the ancient floodplains are still crucial factors in the city's current overland flow behavior. Two types of flooding are proposed: flooding related to natural drainage network (FREN) and flooding unrelated to natural drainage network (FUNN). In order to determine the material damages associated to FREN and FUNN and their spatial distribution, an insurance flooding database (2000-2011) was used. Through the accurate location of the APS (the Portuguese Association of Insurers) database flooding records triggered by rainfall and the reconstruction of the Lisbon's natural drainage network, it was possible to define which type of flooding caused each reported claim.

There are different spatial patterns in Lisbon concerning FREN and FUNN. FREN occurs along the valley bottoms, while FUNN has a more scattered spatial pattern, meaning that FUNN can occur where there are overland flow difficulties. 53\% of the claims were caused by FUNN; however, higher payouts are associated with FREN (58\%). Resorting only to the claims recorded during an extreme rainfall event (in 18 February 2008), the weight of FREN is even more pronounced with $58 \%$ of the claims and $71 \%$ of the payouts. This proves the higher FREN's potential to cause material damages when compared to FUNN's. This knowledge can be applied to the flooding mitigation or adaptation measures to be included in urban planning.
\end{abstract}

Keywords: FREN; FUNN; insurance database; Lisbon; material damages; Urban flooding.

\section{INTRODUCTION}

Material damages caused by flooding in developed countries are increasing due to the built-up areas expansion, population growth and wealth and, possibly, climate change [1-8]. In the European Union, the average annual costs related to flooding reach 4.2 billion $€$ [4].

Flooding is one of the most important, dangerous and destructive natural hazards in the Mediterranean region [8-13]. In Portugal, flooding was the most deadly natural disaster during the $20^{\text {th }}$ century [14], in which the Lisbon Metropolitan Area (LMA) is a particularly affected region. More than half of the total fatalities registered in the country between 1865 and 2010 due to flooding were recorded here [15]. However, most of the mentioned facts are due to (fluvial) floods, mostly flash floods, and not to urban flooding, whose potential to cause damages is lower [16].

There are several terms applied to the flooding that occurs in urban environment, there being no consensus in the scientific community $[17,18]$. Urban flooding is probably the most used, but its definition is not clear. It can be understood as all flooding that occur inside a city [5], or as the flooding that occurs in urban areas as a result of heavy rainfall events, causing overland flow and the surcharging of the drainage systems $[19,20]$. Surface water flooding (SWF) is another concept broadly used, which can be defined as the combined flooding during a heavy rainfall event, in which are included pluvial flooding, sewer flooding, flooding from small open-channel and culverted urban watercourses and overland flows from groundwater springs [17]. Therefore, 
pluvial, sewer or culverted watercourses flooding are more restricted terms/types of flooding, which can be seen as subcategories of urban flooding or SWF [21]. Despite that, some studies do not make any distinction between urban flooding/SWF and pluvial flooding [20, 22].

As was pointed out, there is no consensus and there is an overlap in the extent of these concepts. In these conditions, determining which of these types of flooding was responsible to cause a given occurrence is, in most cases, an error prone task, once it can be triggered by more than one. On the other hand, they should not be included in the same category because they often have different triggering conditions, resulting in different consequences [23]. Considering that, it is proposed a different classification based on hydro-geomorphological criteria: FREN means: flooding related to ancient natural drainage network. FUNN means: flooding unrelated to present or ancient natural drainage network.

The material damages in Lisbon are estimated resorting to an insurance database provided by the APS (the Portuguese Association of Insurers), which is available between January 2000 and October 2011. Through this database, it was possible: (a) to define which records have been caused by each proposed type of flooding; (b) to determine the material damages associated with each type of flooding in Lisbon; (c) to understand if an extreme rainfall event, like the one that occurred in 18 February 2008, is able to produce different consequences and to modify the standard pattern concerning the prevailing type of flooding; and (d) to represent the spatial distribution of material damages in Lisbon.

\section{STUDY AREA}

Lisbon is the Portuguese capital and comprises an area of $85 \mathrm{~km}^{2}$, which represents $3 \%$ of the LMA's area. It is the most built-up municipality of the 18 that compose this region. More than $70 \%$ of its surface corresponds to built-up areas, where 506.892 people lived in 2015.

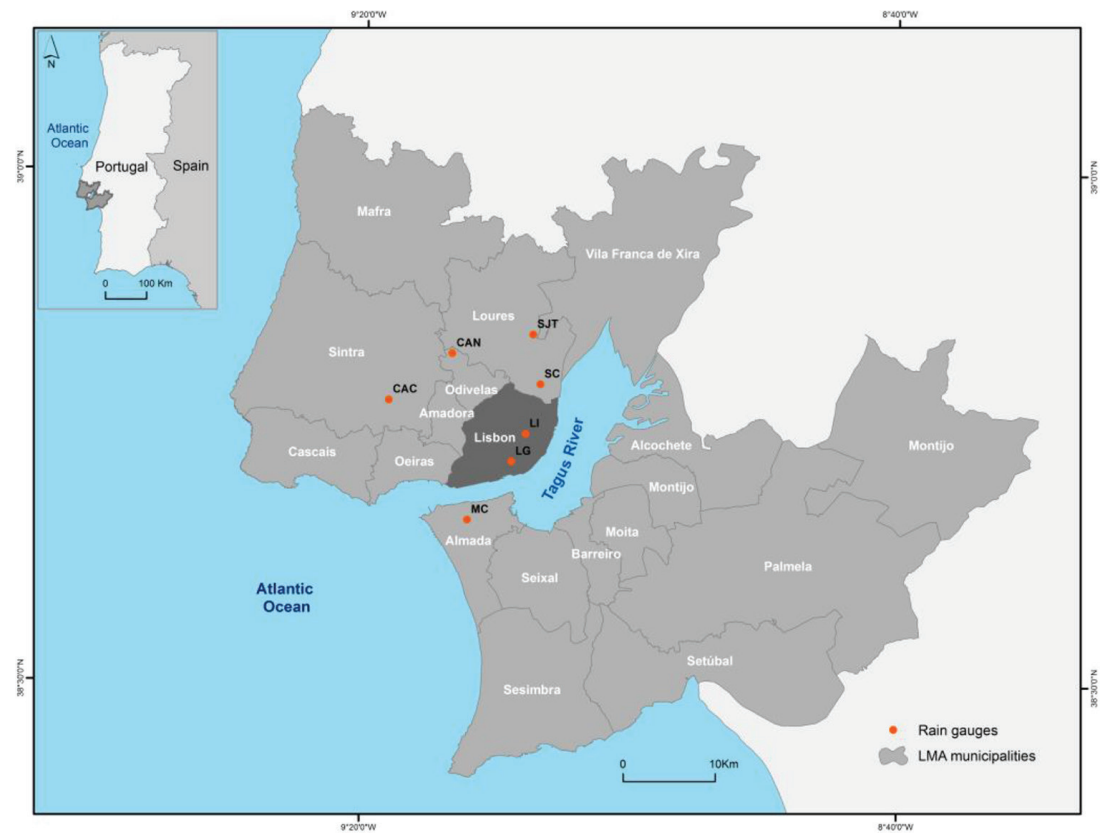

Figure 1: Location of Lisbon, the other LMA municipalities and the rain gauges used. Note: The rain gauges' labels can be found in Table 1 . 
This city is located near the Atlantic coast and in the North bank of the Tagus River (Fig. 1). In Lisbon, elevation ranges between 0 (by the Tagus River) and 227 meters (in the Monsanto Mountain), being known as 'the city of the seven hills' essentially due to the natural hydrographic network action. This municipality is drained by a set of small drainage basins, whose sizes vary between $42 \mathrm{~km}^{2}$ and less than $1 \mathrm{~km}^{2}$. With the exception of some upstream sections, all watercourses were progressively being culverted or buried mainly in the 20th century. As a result, Lisbon is almost exclusively affected by urban flooding.

\section{DATA AND METHODS}

\subsection{The APS database and the support rainfall data}

The APS database stores the material damages caused by flooding for the period between January 2000 and October 2011 in Portugal, comprising about 60\% of the national universe of insurance policies. The APS database records are designated as APS claims, containing data on: (a) communication date (when the APS claim was reported to the insurance company); (b) location based on the postal code (only accurate and localizable with seven digits); (c) capital sum affected; and (d) payouts. Capital sum affected corresponds to the capital sum insured in the insurance policy when an APS claim is reported. Payouts are the amount of money (€) paid by an insurance company to a policyholder when an APS claim is reported (the maximum value is equal to the capital sum affected). The ratio between payouts and capital sum affected is designated by loss. It was calculated for each APS claim and is expressed as a percentage; however, as the overall losses are low, the total results are expressed as per 1000.

An APS event corresponds to a flooding situation triggered by rainfall, causing one or more APS claims. Nevertheless, the APS database has no information about the flooding cause. Thus, there are APS claims caused by rainfall, coastal flooding or when pipes burst in the street or inside home. To fulfil the purpose of this research, it was necessary to define the APS events and to determine which APS claims were triggered by rainfall. To achieve this, the newspapers' information was used. Five hundred and fifty localizable APS claims were identified, corresponding to 57 flooding events related to rainfall.

In order to maximize the number of usable APS claims, daily rainfall data of seven rain gauges inside or near Lisbon were collected (Fig. 1 and Table 1). The Lisboa/Geofísico rain gauge belongs to IPMA (Portuguese Institute for Sea and Atmosphere), whereas the other six

Table 1: Characteristics of the rain gauges collected.

\begin{tabular}{lllllll}
\hline & & & & Number of & $\begin{array}{l}\text { Days with } \\
\text { records }\end{array}$ \\
Code & Rain gauges & $\begin{array}{l}\text { Altitude } \\
(\mathrm{m})\end{array}$ & Start date & End date & $\begin{array}{l}\text { (daily data) } \\
(\%)\end{array}$ \\
\hline CAC & Cacém & 173 & $01-10-1979$ & Active & 10,763 & 81.2 \\
CAN & Caneças & 277 & $01-10-1980$ & Active & 11,731 & 89.9 \\
LG & Lisboa/Geofísico & 77 & $01-10-1941$ & Active & 25,536 & 100 \\
LI & Lisboa/INAG & 52 & $13-01-2005$ & $20-05-2009$ & 1,155 & 72.7 \\
MC & Monte da Caparica & 96 & $01-05-1985$ & Active & 8,456 & 74.3 \\
SC & Sacavém de Cima & 46 & $01-10-1980$ & $30-09-2002$ & 8,035 & 100 \\
SJT & São Julião do Tojal & 6 & $10-01-1955$ & Active & 21,018 & 98.7 \\
\hline
\end{tabular}


rain gauges belong to the SNIRH (National Water Resources Information System) network. This option was taken because there are APS claims not reported in newspapers occurring in dates with high daily rainfall values. So, if at least one of the rain gauges has recorded a value greater than or equal to $20 \mathrm{~mm} /$ day, and there were one or more APS claims in the same date, an APS event is considered and those claims are related to rainfall. The value of $20 \mathrm{~mm} / \mathrm{day}$ is slightly higher than the 90th percentile $(19.8 \mathrm{~mm} /$ day) of the rain gauges (4) with more than 30 years of daily rainfall data. When high rainfall values dates (higher than the 90th percentile) and the APS claims dates are coincident, it was assumed that these claims were triggered by rainfall. One hundred and two more localizable APS claims and 52 more flooding events related to rainfall were detected resorting to this methodology. These correspond to minor events in the amount of APS claims and material damages; otherwise, it would have been reported in newspapers. In total, 652 localizable APS claims and 109 flooding events related to rainfall were accounted for the considered period in Lisbon. Incorrect records (misplaced, duplicated and with missing data) were eliminated.

In the APS database, the claim date may not correspond to the date of the flooding occurrence, but to the date the situation was communicated to the insurance company. The APS estimates that the lag time between the flooding date and the communication date is approximately 5 business days. Therefore, an APS claim related to rainfall was considered when it has occurred up to 5 business days after the last day of a flooding event. When two APS events are less than 5 business days apart, there are some APS claims that may belong to both events, corresponding to $4 \%$ of the total APS claims. In those circumstances, it was decided not to associate those APS claims to any APS event. It must be recognized that the average lag time of 5 business days between the communication date and the flooding date may not allow determining with absolute safety if some APS claims are related to rainfall or not.

The total number of localizable APS claims for the 2000-2011 period (652) corresponds to $56 \%$ of the total of claims reported in the APS database for Lisbon, which is a very acceptable sample to achieve the goals of this paper.

\subsection{Classification and determination of types of flooding}

The APS claims were classified as FREN and FUNN. All the situations occurred in places where there are (through pipes) or there were watercourses are FREN. This includes: flooding from culverted watercourses, flooding from buried watercourses and flooding from old watercourse routes. To a certain extent, FREN corresponds nowadays to the floods that occurred in small streams before the land artificialization. This type of flooding occurs along the Lisbon's ancient floodplains, proving that the relief is still a crucial factor in the city's current overland flow behavior [24]. All the situations not related to natural drainage network are FUNN, which means that their occurrence is not influenced by watercourses. FUNN occurs in flat areas, low-lying areas and natural depressions. It can also occurs when grated inlets are obstructed by leaves or debris and whenever there are situations of overland flow blocking, whether they are natural or human induced. This type of flooding is highly related to the urban grid features.

Through the location of the APS claim, its hydro-geomorphological context (floodplains, valley bottoms or topographic natural depressions) and the reconstruction of the natural drainage network (using a set of the 19th and the 20th centuries topographic maps with 1:10,000 or 1:25,000 scales), it was possible to determine the type of flooding for each APS claim. 


\section{RESULTS}

\subsection{The APS database global results for Lisbon}

Through the APS database, 109 flooding events with material damages were identified in Lisbon between January 2000 and October 2011, causing 652 localizable APS claims (55 per year) and 2,266,083 $€$ in payouts (191,500 $€$ per year). On average, 6 APS claims and 20,790 $€$ of payouts per event were registered.

The 18 February 2008 event had a major influence in the APS database: 161 claims $(25 \%$ of the Lisbon's total) and 1,020,521 $€$ of payouts (45\% of the Lisbon's total). The second most important event (29 October 2010) totalled 41 APS claims and $134,725 €$ in payouts. The 2008 event can be considered an extreme rainfall event, fitting in what Fragoso [25] defined as a torrential rainfall episode for the LMA (greater than or equal to $100 \mathrm{~mm} /$ day). In the São Julião do Tojal rain gauge (SJT - Fig. 1 and Table 1), which is often used as the reference rain gauge for the LMA due to the duration and reliability of the daily rainfall series [26], $140.9 \mathrm{~mm}$ in $24 \mathrm{~h}$ were registered. This value exceeded by far the average monthly value of February in this rain gauge $(89.4 \mathrm{~mm})$, being only surpassed by the value recorded in 18 November 1983 (163.7 mm/day). The other record above $100 \mathrm{~mm} /$ day in the SJT rain gauge was registered in 25/26 November 1967 (137 mm), when a very destructive flooding event caused about 700 fatalities [14]. Considering the Lisboa/Geofísco rain gauge (located inside the Lisbon municipality - Figure 1 and Table 1), the highest value in its daily rainfall series was recorded during the 2008 event (118.4 mm).

Lisbon is the LMA's municipality with the highest number of APS claims (33\%) and payouts (36\%). Payouts per claim reached $3471 €$ in Lisbon, being above the LMA's average (3229 €). This is partly explained by the fact of being the most built-up municipality (73\%). Impervious surfaces lead to increases in volume and speed of overland flow [27-29], and, consequently, to increases in flooding frequency and magnitude [17, 30-32]. Lisbon has also the highest number of insurance policies (22\%), dwellings (22\%) and inhabitants (19\%), which means a higher flooding exposure. On the other hand, factors like the hydro-geomorphological and the urban grid features, the undersized urban drainage network and the tidal influence contribute to the high amount of APS claims in Lisbon.

The Portuguese capital suffers the effects of urban flooding with some frequency, being a heavy rainfall episode that lasts a couple of hours enough to cause damages. Resorting to the APS database, it is possible to confirm that a high number of APS claims are not necessarily demanding of big rainfall events. In fact, the same amount of rainfall can cause few or many APS claims, or may not even trigger any APS claim. This is expressed by the low correlation coefficient $(r=0.51)$ between the number of APS claims per event in Lisbon and the daily rainfall values recorded in the Lisboa/Geofísico rain gauge. Several factors can explain this: (a) the quality and availability of rainfall and insurance data [33, 34]; (b) the spatial and temporal distribution of the triggering rainfall; (c) the geomorphological, lithological and hydrological features; (d) the extent of built-up areas; (e) the amount of exposed (and insured) dwellings; (f) the capacity of the stormwater drainage systems to cope with heavy rainfall events; (g) the obstruction by leaves or debris of the grated inlets [35]; (h) the urban grid features; and (i) the tidal and/or storm surge influence. 


\subsection{Types of flooding and their spatial distribution}

All the previously mentioned factors make Lisbon particularly prone to urban flooding. However, the water depth and volume reached used to be low [24]. This partially justifies the absence of fatalities in this municipality since $1966[15,16]$. The progressive culverting of Lisbon's watercourses in the 1940s, 1950s and 1960s led to the disappearance of flash floods, which is the most dangerous type of flooding in the Mediterranean region [13]. Despite the human damages caused by flooding are currently low, the same does not happen with material damages.

During the analyzed period, Lisbon achieved $36 \%$ of the APS claims caused by urban flooding (FREN and FUNN) recorded in the LMA. It should not be forgotten that this municipality occupies only $3 \%$ of the LMA's area, showing the weight of the Lisbon's urban flooding in this region.

As expected, FREN and FUNN have distinct behaviors regarding the amount of claims and the consequences both are capable of generate. This is predictable due to their proper characteristics and the places where these types of flooding occur. FREN only takes place along the ancient floodplains, presenting high densities of APS claims in some sectors located in the most important Lisbon's drainage basins (Fig. 2). On the contrary, FUNN has a scattered pattern, which is more dependent on the urban grid (Fig. 2). Generally, rainwater is ponded where there are overland flow difficulties due to blocking situations or in flat areas, having no relation with drainage basins.

Considering the total records, FUNN presented a higher number of APS claims (53\%) (Fig. 3a), which is understandable taking into account the larger area that may be affected by this type of flooding. Nevertheless, FREN was able to cause higher payouts (58\%) (Fig. 3b). In order to eliminate the effect of the absolute numbers, payouts per claim were obtained (Fig. 3c).

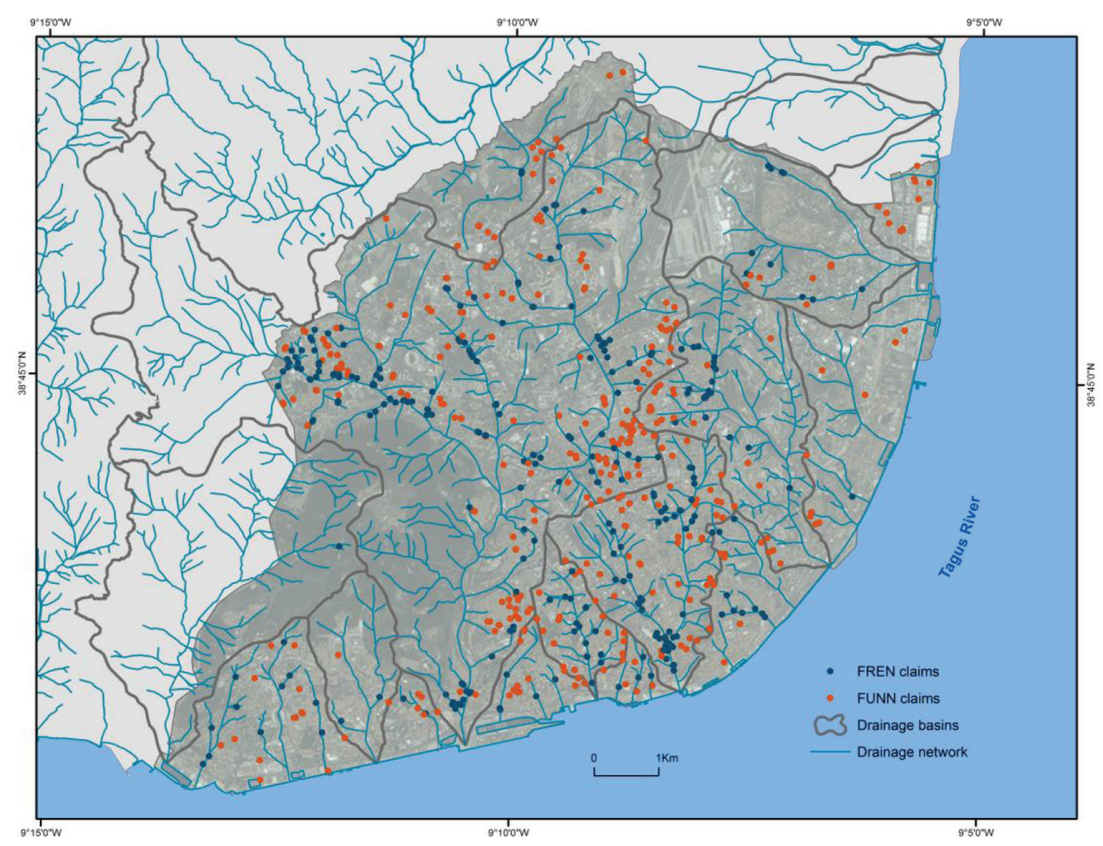

Figure 2: Spatial distribution of FREN and FUNN claims in Lisbon. 


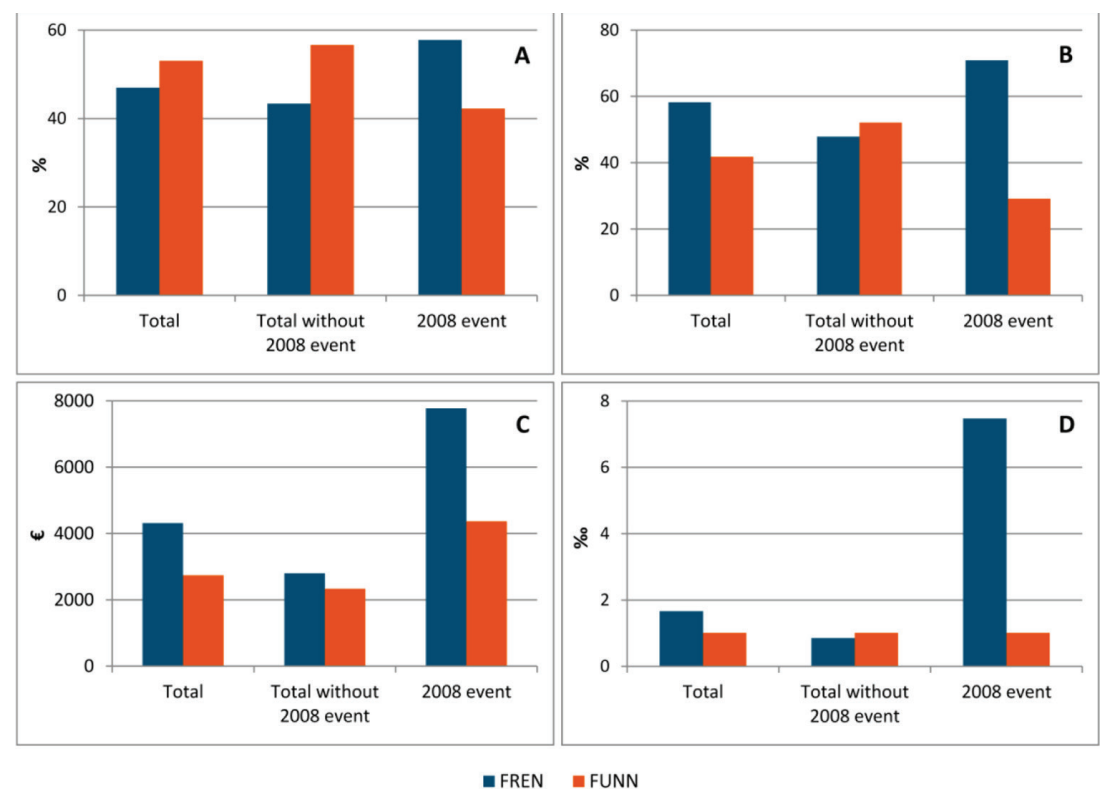

Figure 3: Material damages per type of flooding (2000-2011) in Lisbon: (a) APS claims, (b) Payouts, (c) Payouts per APS claim, (d) Losses.

This relation pointed in the same direction. FREN had $4313 €$ per claim and FUNN had 2735 $€$ per claim. Losses in FREN were also higher than in FUNN (1.66\%o against 1.01\%o) (Fig. 3d).

As it was previously said, the 2008 event has a major relevance in the APS database. This event highlighted the weight of FREN in the material damages recorded for Lisbon. Isolating the 2008 event, this type of flooding was responsible for a higher number of claims (58\%), payouts $(71 \%)$, payouts per claim (7779€ against $4370 €)$ and losses (7.48\%o against $1.01 \%$ o) when compared to FUNN (Fig. 3).

The weight of this event in the total records can be seen if it is excluded (total without the 2008 event - Figure 3). In fact, if the 2008 event had never happened, the results would be substantially different, once payouts per claim would drop $1513 €$ in FREN and $400 €$ in FUNN. On the other hand, the prevalence of FREN would no longer exist because APS claims, payouts and losses would be higher for FUNN (Fig. 3). The only exception would be payouts per claim, in which FREN would continue to present a higher value.

\section{DISCUSSION AND CONCLUSIONS}

The APS database was used in this research to determine the location of the flooding claims triggered by rainfall and to account the material damages caused by this natural hazard in Lisbon. The spatial planning decisions mainly taken in the 1940s, 1950s and 1960s, by culverting the majority of the watercourses, led to the flash floods disappearance. However, the expansion of built-up areas has increased the urban flooding problems, since increases in volume and speed of the overland flow are generated, and the stormwater drainage systems design capacity is frequently exceeded during heavy rainfall events.

Six hundred and fifty-two APS claims with an accurate location were registered in Lisbon between January 2000 and October 2011. However, it is necessary to take into account that the 
material damages reported here are an estimation of the total material damages occurred in Lisbon in the studied period because: (a) the 652 localizable APS claims only correspond to $56 \%$ of the total APS claims recorded by the APS database in the study area; (b) not all residential, commercial and industrial spaces have insurance policies; (c) insurance companies may refuse to make or to renew an insurance policy or they may require a very high premiums due to past flooding occurrences; (d) payouts generally do not cover all damages, because there are limits stablished in the insurance policies or some types of damages may not be included [19]; and (e) the paid amounts depend on the evaluation of the insurance companies' experts.

Lisbon presented the highest number of APS claims and payouts of the 18 municipalities that compose the LMA. Beyond the hydro-geomorphological and urban grid features, also the largest percentage of built-up areas, the highest capital sum insured and the highest number of insurance policies, dwellings and inhabitants can influence this result. It must be kept in mind that the APS database only comprises buildings insurance policies. Thus, the higher the building densities, the higher the flooding exposure.

In Lisbon, FUNN was the most common type of flooding, presenting a scattered spatial pattern. If valley bottoms are excluded, FUNN can practically occur wherever there is a (exposed) building. Nevertheless, FREN reached higher payouts, payouts per claim and losses, being essentially concentrated in some critical sectors of the main drainage basins. These facts confirm the FREN's larger destructive potential. This is even more notorious when an extreme rainfall event, like the 2008 event, occurs. The presented numbers and values support the idea that, when a high magnitude rainfall event occurs, the relief is the key factor in Lisbon and, in practice, the ancient watercourses respond in a similar way as before they were culverted. This happens because the overland flow is directed to the built-up valley bottoms, not being able to enter into the drainage system. In these cases, watercourses are formed along the streets, in the same places they existed before. In this sense, high magnitude rainfall events more easily cause FREN and the more frequent events (with lower magnitude) tend to trigger FUNN, there being less likely to cause FREN.

Based on the precise location of APS claims and the Lisbon's hydro-geomorphological features, two types of flooding are proposed. Given the difficulties in defining which of the normally used types of flooding (pluvial flooding, sewer flooding or other) causes a given APS claim, the separation in FREN and FUNN can be an important contribution in this matter. Resorting to this classification, it is possible to determine the material damages caused by two different types of flooding that occur in urban areas. This knowledge can be applied to the flooding mitigation or adaptation measures to be included in urban planning.

\section{ACKNOWLEDGEMENTS}

The authors thank the Portuguese Association of Insurers (APS) and the CIRAC project (Floods and Risk in Climate Change Scenarios) for their support and for providing the insurance data used in this research. Miguel Leal was funded by the Portuguese Science and Technology Foundation (FCT) through grant SFRH/BD/96632/2013.

\section{REFERENCES}

[1] Mills, E., Insurance in a climate of change. Science, 309, pp. 1040-1044, 2005. https://doi.org/10.1126/science.1112121 
[2] Botzen, W. J. W., van den Bergh, J. C. J. M. \& Bouwer, L. M., Climate change and increased risk for the insurance sector: A global perspective and an assessment for the Netherlands. Natural Hazards, 52, pp. 577-598, 2010. https://doi.org/10.1007/s11069-009-9404-1

[3] Aerts, J. C. J. H. \& Botzen, W. J. W., Climate change impacts on pricing long-term flood insurance: A comprehensive study for the Netherlands. Global Environmental Change, 21, pp. 1045-1060, 2011. https://doi.org/10.1016/j.gloenvcha.2011.04.005

[4] Jongman, B., Hochrainer-Stigler, S., Feyen, L., Aerts, J.C.J.H., Mechler, R., Botzen, W.J.W., Bouwer, L.M., Pflug, G., Rojas, R. \& Ward, P.J., Increasing stress on disaster-risk finance due to large floods. Nature Climate Change, 4, pp. 264-268, 2014. https://doi.org/10.1038/nclimate2124

[5] Hammond, M.J., Chen, A.S., Djordjević, S., Butler, D. \& Mark, O., Urban flood impact assessment: a state-of-the-art review. Urban Water Journal, 12, pp. 14-29, 2015. https://doi.org/10.1080/1573062x.2013.857421

[6] Paudel, Y., Botzen, W. J. W. \& Aerts, J. C. J. H., Influence of climate change and socioeconomic development on catastrophe insurance: a case study of flood risk scenarios in the Netherlands. Regional Environmental Change, 15, pp. 1717-1729, 2015. https://doi.org/10.1007/s10113-014-0736-3

[7] Surminski, S., Aerts, J.C.J.H., Botzen, W.J.W., Hudson, P., Mysiak, J. \& PPrez-Blanco, C.D., Reflections on the current debate on how to link flood insurance and disaster risk reduction in the European Union. Natural Hazards, 79, pp. 1451-1479, 2015. https://doi.org/10.1007/s11069-015-1832-5

[8] Diakakis, M., Deligiannakis, G., Pallikarakis, A. \& Skordoulis, M., Factors controlling the spatial distribution of flash flooding in the complex environment of a metropolitan urban area. The case of Athens 2013 flash flood event. International Journal of Disaster Risk Reduction, 18, pp. 171-180, 2016. https://doi.org/10.1016/j.ijdrr.2016.06.010

[9] Llasat, M.C., Llasat-Botija, M., Barnolas, M., López, L. \& Altava-Ortiz, V., An analysis of the evolution of hydrometeorological extremes in newspapers: the case of Catalonia, 1982-2006. Natural Hazards and Earth System Science, 9, pp. 1201-1212, 2009. https://doi.org/10.5194/nhess-9-1201-2009

[10] Llasat, M.C., Llasat-Botija, M., Prat, M.A., Porcú, F., Price, C., Mugnai, A., Lagouvardos, K., Kotroni, V., Katsanos, D., Michaelides, S., Yair, Y., Savvidou, K. \& Nicolaides, K., Highimpact floods and flash floods in Mediterranean countries: the FLASH preliminary database. Advances in Geosciences, 23, pp. 47-55, 2010.

https://doi.org/10.5194/adgeo-23-47-2010

[11] Camarasa-Belmonte, A.M. \& Soriano-García, J., Flood risk assessment and mapping in peri-urban Mediterranean environments using hydrogeomorphology. Application to ephemeral streams in the Valencia region (eastern Spain). Landscape and Urban Planning, 104, pp. 189-200, 2012. https://doi.org/10.1016/j.landurbplan.2011.10.009

[12] Ruiz-Bellet, J.L., Balasch, J.C., Tuset, J., Barriendos, M., Mazon, J. \& Pino, D., Historical, hydraulic, hydrological and meteorological reconstruction of 1874 Santa Tecla flash floods in Catalonia (NE Iberian Peninsula). Journal of Hydrology, 524, pp, 279-295, 2015.

https://doi.org/10.1016/j.jhydrol.2015.02.023 
[13] Pereira, S., Diakakis, M., Deligiannakis, G. \& Zêzere, J.L., Comparing flood mortality in Portugal and Greece (Western and Eastern Mediterranean). International Journal of Disaster Risk Reduction, 22, pp. 147-157, 2017. https://doi.org/10.1016/j.ijdrr.2017.03.007

[14] Ramos, C. \& Reis, E., Floods in Southern Portugal: their physical and human causes. Mitigation and Adaptation Strategies for Global Change, 7, pp. 267-284, 2002. https://doi.org/10.1023/a:1024475529524

[15] Zêzere, J.L., Pereira, S., Tavares, A.O., Bateira, C., Trigo, R.M., Quaresma, I., Santos, P.P., Santos, M. \& Verde, J., DISASTER: A GIS database on hydro-geomorphologic disasters in Portugal. Natural Hazards, 72, pp. 503-532, 2014.

https://doi.org/10.1007/s11069-013-1018-y

[16] Pereira, S., Zêzere, J.L. \& Quaresma, I., Mortality associated to hydro-geomorphologic disasters in the Great Lisbon area in the last 150 years. International Conference on Urban Risks, Lisbon, 2016.

[17] Falconer, R.H., Cobby, D., Smyth, P., Astle, G., Dent, J. \& Golding, B., Pluvial flooding: New approaches in flood warning, mapping and risk management. Journal of Flood Risk Management, 2, pp. 198-208, 2009.

https://doi.org/10.1111/j.1753-318x.2009.01034.x

[18] Priest, S.J., Parker, D.J., Hurford, A.P., Walker, J. \& Evans, K., Assessing options for the development of surface water flood warning in england and wales. Journal of Environmental Management, 92, pp. 3038-3048, 2011. https://doi.org/10.1016/j.jenvman.2011.06.041

[19] CNT. The prevalence and cost of urban flooding: a case study of cook county, IL. Center for Neighborhood Technology, 2014.

[20] Yu, D. \& Coulthard, T.J., Evaluating the importance of catchment hydrological parameters for urban surface water flood modelling using a simple hydro-inundation model. Journal of Hydrology, 524, pp. 385-400, 2015.

https://doi.org/10.1016/j.jhydrol.2015.02.040

[21] Parker, D.J., Priest, S.J. \& McCarthy, S.S., Surface water flood warnings requirements and potential in England and Wales. Applied Geography, 31, pp. 891-900, 2011. https://doi.org/10.1016/j.apgeog.2011.01.002

[22] Pitt, M., Learning lessons from the 2007 floods. Floods Review, 2008. https://doi.org/10.1007/s13398-014-0173-7.2.

[23] Jha, A.K., Bloch, R. \& Lamond, J., Cities and flooding: a guide to integrated urban flood risk management for the 21st century. Journal of Regional Science, 52(5), pp. 885-887, 2012. https://doi.org/10.1596/978-0-8213-8866-2

[24] Oliveira, P.E. \& Ramos, C., Inundações na cidade de Lisboa durante o século XX e seus factores agravantes. Finisterra, 74, pp. 33-54, 2002.

[25] Fragoso, M., O contexto atmosférico dos episódios de precipitações intensas no Sul de Portugal. Relatório 39, Área de Investigação de Geografia Física e Ambiente, Centro de Estudos Geográficos, Lisbon, 2004. ISBN: 972-636-148-6.

[26] Trigo, R.M., Ramos, C., Pereira, S.S., Ramos, A.M., Zêzere, J.L. \& Liberato, M.L.R., The deadliest storm of the 20th century striking Portugal: Flood impacts and atmospheric circulation. Journal of Hydrology, 541, pp. 597-610, 2016. https://doi.org/10.1016/j.jhydrol.2015.10.036 
[27] Patton, P., Drainage basin morphometry and floods. In: V. Baker, R. Kochel, \& P. Patton, (eds) Flood geomorphology. Wiley, New York, pp. 51-65, 1988. ISBN: 978-0471625582.

[28] Smith, L. \& Ward, R., Floods: physical processes and human impacts. Wiley, Chichester, 1998. ISBN: 978-0-471-95248-0

[29] Butler, D. \& Davies, J.W., Urban drainage. 2nd edition. Spon Press, London, 2004. ISBN: 0-203-34190-2.

[30] Suriya, S., Mudgal, B.V. \& Nelliyat, P., Flood damage assessment of an urban area in Chennai, India, part I: Methodology. Natural Hazards, 62, pp. 149-167, 2012. https://doi.org/10.1007/s11069-011-9985-3

[31] Huong, H.T.L. \& Pathirana, A., Urbanization and climate change impacts on future urban flooding in Can Tho city, Vietnam. Hydrology and Earth System Sciences, 17, pp. 379-394, 2013. https://doi.org/10.5194/hess-17-379-2013

[32] Chen, C.F. \& Liu, C.M., The definition of urban stormwater tolerance threshold and its conceptual estimation: An example from Taiwan. Natural Hazards, 73, pp. 173-190, 2014. https://doi.org/10.1007/s11069-013-0645-7

[33] Merz, B., Kreibich, H., Thieken, A. \& Schmidtke, R., Estimation uncertainty of direct monetary flood damage to buildings. Natural Hazards and Earth System Science, 4, pp. 153-163, 2004. https://doi.org/10.5194/nhess-4-153-2004

[34] Spekkers, M.H., Kok, M., Clemens, F.H.L.R. \& Ten Veldhuis, J.A.E., A statistical analysis of insurance damage claims related to rainfall extremes. Hydrology and Earth System Sciences, 17, pp. 913-922, 2013. https://doi.org/10.5194/hess-17-913-2013

[35] Cherqui, F., Belmeziti, A., Granger, D., Sourdril, A. \& Le Gauffre, P., Assessing urban potential flooding risk and identifying effective risk-reduction measures. Science of The Total Environment, 514, pp. 418-425, 2015. https://doi.org/10.1016/j.scitotenv.2015.02.027 